\title{
The Failure of Union Citizenship Beyond the Single Market
}

\author{
Daniel Thym
}

Floris de Witte's defence of free movement presents us with a decidedly non-economic vision of cross-border mobility. It is this normative dimension which connects his argument to broader debates on Union citizenship whose 'core' he considers to be free movement. His thinking builds upon the rich tradition of institutional practices and academic reconstruction that has highlighted the non-economic value of the original market freedoms ever since the late 1960s - the period when the EU legislature opted for generous implementing legislation on the basis of which the ECJ later advanced citizens' rights in cases with purely corollary economic aspects.

I accept this normative starting point and yet will highlight its limited reach nonetheless. De Witte concentrates on the potential of free movement in correcting outcomes at national level without connecting the evolution of citizens' rights to constitutional trends at European level. However, such a broader outlook could help explain the volatile state of Union citizenship at this juncture. I will argue that restrictive tendencies appear as epitaphs of a Union losing self-confidence as a supranational polity, emphasising instead the continued significance of solidary political communities at national level. If we want Union citizenship to thrive, we have to move beyond a minimalist reading.

\section{Correcting the nation-state}

I subscribe to De Witte's defence of free movement as emancipation without hesitation, but want to ask: is that all? Much of the liberty he associates with intra-European mobility is guaranteed as a matter of domestic or international human rights law anyway, which, together with changing selfperceptions of Western societies, considerably extended the degree of private and public choice in recent decades. Gays and lesbians may move to the big cities in their home state to find (relative) freedom - and German pensioners can settle in my current hometown of Konstanz or other 
domestic cities known for their quality of life instead of relocating to Spain. To be sure, European rules extend our freedom geographically and in substance, but the surplus remains gradual instead of categorical.

The same can be said about his third contention on separating 'the nation' from 'the state'. Here he subscribes to an essentially corrective vision of supranational citizenship. Again, I do not take issue with his analysis as a matter of principle, but wonder about the degree of normative value involved. Arguably, the separation between the nation and the state defended by De Witte is no longer a novelty for most (Western) European societies. Nationality law is a perfect prism to highlight changing self-perceptions: two decades ago, ethno-cultural foundations of national identity were pertinent in many Member States. Immigrants obtained certain rights, but their status could be described as a form of 'denizenship', which stopped short of full membership through the formal acquisition of nationality and equal participation in the public realm. ${ }^{1}$ Today, the picture looks different: some Member States moved towards ius soli and essentialist definitions of national identity are being supplanted by various degrees of civic-pluralistic identities. $^{2}$

To be sure, European integration may have been instrumental in bringing about this adjustment through more than its rules on free movement. Such change also remains an ongoing challenge characterised by ups and downs and occasional backlashes. While it is well advanced across Western Europe (notwithstanding the surge of populist movements whose success can be rationalised, in part at least, as a reaction to social change), some countries in Central and Eastern Europe are still in need of similar metamorphoses, in which the corrective potential of European rules described by De Witte may play a beneficial role (as recent developments in Poland and Hungary illustrate). But this does not unmake the move towards inclusionary nationality laws and civic-pluralistic identities. If that is correct, the emancipatory dimension of transnational mobility remains limited. It may reinforce a trend whose dynamism, however, is not intrinsically linked to Union citizenship.

1 See Hammar, T. (1990), Democracy and the Nation-State. Aliens, Denizens and Citizens in a World of International Migration. Aldershot: Avebury.

2 See Joppke, C. (2010), Citizenship and Immigration. Cambridge: Polity Press, chs $2,4$. 
Moreover, broader societal debates on the impact of immigration across Europe illustrate that the corrective reading of transnational mobility defended by De Witte remains mostly negative. It invites European societies to abandon essentialist self-perceptions, but does not contribute much to how the normative foundations of social cohesion should be construed instead. The EU's vision of 'a society in which pluralism, non-discrimination, tolerance, justice, solidarity and equality between women and men prevail' (Article 2 TEU) or the ECHR's standard invocation of 'pluralism, tolerance and broadmindedness' as hallmarks of a democratic society which are supposed to structure the proportionality assessment often remain hollow. That is why De Witte's vision of free movement reinforcing emancipation at national level remains a thin normative account.

\section{Access to social benefits as a test case}

Equal access to social benefits has received much attention in scholarly treatises on Union citizenship over the years, but only recently has it caused widespread political frictions. One reason for the limited impact of the original equal treatment guarantee may have been that it concerned those who were engaged in some sort of economic activity. For such scenarios, the Court extended the range and vigour of equal treatment against restrictive national laws, but the principle itself was uncontroversial, since most Member States had embraced territoriality as the door-opener for workrelated social benefits anyway. Moreover, free movement did not substitute national policy preferences with a supranational vision of social justice. Britain and Sweden had to treat equally Union citizens who were economically active, but this did not affect the distinct structure of their welfare state. $^{3}$ Again, free movement rules reinforced a trend which took place anyway.

Against this background, the central novelty of the original free movement provisions was not equal treatment of those engaged in economic activities, but access to the labour market. To this date, the central difference between a Polish and a Ukrainian national who wants to work in Amsterdam

3 See Thym, D. (2013), 'Towards "Real" Citizenship? The Judicial Construction of Union Citizenship and its Limits', in: M. Adams et al. (eds.), Judging Europe's Judges. The Legitimacy of the Case Law of the European Court of Justice, 155-174. Oxford: Hart. 
is not equal treatment once they have taken up work. The added value of Union citizenship is the right to be admitted to the labour market - a distinction fortified by Article 15 of the Charter of Fundamental Rights which guarantees equal working conditions to everyone, but reserves the right to seek employment in any Member State to Union citizens.

That right to be economically active across the Union is firmly inscribed into the DNA of the European project, since it presents itself as one of the pillars of the single market. We may question the outer limits of corresponding equal treatment, such as in-work benefits for part-time workers or the level of child benefits for children living in another Member State, which feature prominently in the new deal the British government promotes in the run-up to the Brexit referendum. But such disputes about the fringes should not distract from the essentially economic rationale of equal treatment for those who are economically active, which De Witte himself proposed to reconstructed as an expression of a Durkheimian organic solidarity. ${ }^{4}$ The internal market provides the frame for this arrangement. Its pan-European reach remains largely uncontested.

In relation to citizens like Ms Dano the picture looks different. Their status transcends the single market and emanates directly from the rights attached to Union citizenship. Their reach had never been subject to a principled political consensus - as the emphasis on 'limitations and conditions' (Article 21.1 TFEU) in primary law illustrates in the same way as the compromise formulae enshrined in the Citizenship Directive 2004/38/EC. ${ }^{5}$ That is not to say that the Court was right to flatly deny equal treatment to citizens like Ms Dano: a different position could have been defended. ${ }^{6}$ All I say is that we cannot expect the single market case law to be extended to noneconomic activities indefinitely, since the constitutional frame of reference differs. It builds upon the (vague) idea of political union of which generic free movement rights for the economically inactive were always an integral part. ${ }^{7}$ Arguably, it is this connection to political union, which explains the failure of citizens' rights beyond the single market.

4 Cf. de Witte, F. (2015), Justice in the EU. The Emergence of Transnational Solidarity. Oxford: OUP.

5 See Hailbronner, K. (2015), 'Union Citizenship and Access to Social Benefits', Common Market Law Review 42 (5): 1245 (1258-1264).

6 See Thym, D. (2015), 'The Elusive Limits of Solidarity. Residence Rights of and Social Benefits for Economically Inactive Union Citizens', Common Market Law Review 52 (1): 17-50.

7 See Wiener, A. (1998), Building Institutions. The Developing Practice of European Citizenship. Boulder, CO: Westview Press. 


\section{Connecting to the Union as a whole}

Twenty years ago, the European Union could reasonably be considered a political union in the making. Union citizenship could be perceived, like direct elections to the European Parliament or the ill-fated Constitutional Treaty, as a building block of the EU constituting itself as a supranational political community based upon meaningful public discourse and a functioning 'representative democracy' (Article 10.1 TEU). The famous dictum of the Court that citizenship was 'destined' to be a fundamental status arguably hinted at this forward-looking aspiration. A vision of social justice embracing the fight against social exclusion, whose absence in the Dano judgment De Witte criticises, would undoubtedly have been an integral part of such supranational polity (see Article 34 Charter of Fundamental Rights).

We all know that the state of the EU is a different one at this juncture. The confidence that some sort of political union would be forthcoming was seriously damaged after the failure of the Constitutional Treaty, as a result of the eurocrisis and regarding the surge of anti-European populism. That is why a continuation of the trend towards ever more citizens' rights was no forgone conclusion. Indeed, the Dano judgment is not the only example in which the ECJ refrained from developing its vision of social justice: not assessing austerity measures in light of the Charter is another example. ${ }^{8}$ By deciding not to engage in such debates, the Court signalled that it would not develop a thick reading of citizens' rights. This hands the initiative back into the domestic arena. National constitutional courts or the ECHR will ultimately have to decide the fate of Ms Dano. ${ }^{9}$ The ECJ abdicated responsibility in the same way as it handed questions of family unity in purely domestic situations back to national courts and the ECHR. ${ }^{10}$

$8 \quad$ See José Menéndez, A. (2014), 'Which Citizenship? Whose Europe?-The Many Paradoxes of European Citizenship', German Law Journal 15 (907): 928-931.

9 After the German Federal Social Court had granted Ms Dano (and some other Union citizens who are economically inactive) a right to social benefits on the basis of statutory rules, the Merkel government announced a change in the law, which would ultimately require the German Constitutional Court to decide whether Union citizens can be expected to return to their home state to obtain social benefits.

10 Cf. ECJ, Dereci u.a., C-256/11, EU:C:2011:734, paras 70-74. 
This leaves us with the overall conclusion that any fortification of citizens' rights beyond the single market remains linked to broader constitutional trends. If we want the Court to employ citizens' rights to foster a supranational vision of social justice, we arguably have to move beyond a minimalist reading of free movement as correcting unwelcome outcomes at national levels. What would be required, instead, is a vision of social justice for the Union as a whole, not only for those moving to other Member States.

Open Access This chapter is licensed under the terms of the Creative Commons Attribution 4.0 International License (http://creativecommons.org/licenses/by/4.0/), which permits use, sharing, adaptation, distribution and reproduction in any medium or format, as long as you give appropriate credit to the original author(s) and the source, provide a link to the Creative Commons license and indicate if changes were made.

The images or other third party material in this chapter are included in the chapter's Creative Commons license, unless indicated otherwise in a credit line to the material. If material is not included in the chapter's Creative Commons license and your intended use is not permitted by statutory regulation or exceeds the permitted use, you will need to obtain permission directly from the copyright holder. 